\author{
Andrzej Raczyk \\ Zakład Zagospodarowania Przestrzennego \\ Instytut Geografii i Rozwoju Regionalnego \\ Uniwersytet Wrocławski
}

\title{
Metody badania przedsiębiorczości oparte na rejestrze podmiotów gospodarki narodowej
}

Jednym z najważniejszych problemów związanych z badaniem przedsiębiorczości na poziomie lokalnym jest dostępność oraz jakość danych gromadzonych przez statystykę publiczną. W badaniach naukowych w Polsce najczęściej wykorzystywanym źródłem informacji na ten temat jest Krajowy Rejestr Urzędowy Podmiotów Gospodarki Narodowej (REGON) prowadzony przez GUS. Analizę rejestru REGON poważnie utrudnia jego nadreprezentacyjność oraz nieaktualność zawartych w nim informacji. Brak szczegółowych informacji o skali tego zjawiska powoduje problemy w interpretacji uzyskanych wyników. Stawia również pod znakiem zapytania ich prawdziwość.

Podstawowym celem badania była weryfikacja kompletności i aktualności rejestru podmiotów gospodarki narodowej z punktu widzenia informacji opisujących te jednostki (status, lokalizacja, liczba pracujących). Sprawdzono ponadto, czy obserwowane różnice między statystyczną liczbą jednostek a ich liczbą realną wykazują prawidłowości w układach rodzajowych (sekcji PKD) i przestrzennych. Dokonano tego poprzez badanie ankietowe wszystkich istniejaccych podmiotów gospodarczych oraz porównanie zebranych danych z rejestrem REGON. Z uwagi na skalę badań analizę przeprowadzono na przykładzie miasta średniej wielkości (gmina miejska Milicz). Niezbędne materiały zostały pozyskane w trakcie dwóch badań terenowych przeprowadzonych w czerwcu 2006 r. i 2007 r.

Procedura badawcza polegała na weryfikacji informacji zawartych w rejestrze REGON w odniesieniu do wszystkich podmiotów gospodarki narodowej w nim zarejestrowanych. Dane wyjściowe pochodziły z Urzędu Statystycznego we Wrocławiu i obejmowały stan z 30.04.2006 r., a więc okresu bezpośrednio poprzedzającego badanie. Łącznie obejmowały one 1563 jednostki. W trakcie analizy weryfikowano następujące informacje:

- status jednostki,

- główny profil działalności,

- lokalizacja (,widzialna” - „niewidzialna” przestrzeń instytucjonalna),

- liczba pracujących.

W trakcie badania największe problemy stwarzało pozyskiwanie informacji związanych z liczbą pracujących w poszczególnych podmiotach gospodarczych. Wynikła z tego konieczność przeprowadzenia szacunków. Pozostałe informacje zebrano dla wszystkich jednostek.

\section{Definicje przedsiębiorczości i sposoby jej pomiaru}

Przedsiębiorczość, obok konkurencyjności i innowacyjności, stała się w ostatnich latach jednym z istotniejszych zagadnień związanych z analizą procesów wzrostu ekonomicznego. 
Jest przy tym traktowana jako ważny wyznacznik tego wzrostu. Świadczy o tym chociażby rola przypisywana rozwojowi przedsiębiorczości zarówno w oficjalnych dokumentach dotyczących kreowania polityki regionalnej na poziomie krajowym i regionalnym (por. Sechster..., 1999; Narodowa strategia..., 2000; Narodowy Plan..., 2003), jak również w wielu opracowaniach naukowych (por. Bagdziński, Konkel 1997, Chmiel 1997, Kayne 1999, Reynolds, Hay, Camp 1999).

W warunkach polskich, wobec przedłużającej się prywatyzacji przedsiębiorstw sektora publicznego, powstawanie nowych podmiotów gospodarczych determinowało w zasadzie tempo przekształceń struktur własnościowych. Przyczyniało się ono ponadto do znacznego łagodzenia negatywnych skutków społecznych procesów restrukturyzacyjnych zachodzących w przedsiębiorstwach (ograniczanie bezrobocia). Na podstawie dotychczasowych doświadczeń można stwierdzić, że dynamiczny rozwój przedsiębiorczości warunkował pomyślność całego procesu zmian systemowych, szczególnie w jego początkowym okresie (Raczyk 1999).

Pomimo bardzo bogatej literatury dotyczącej przedsiębiorczości ${ }^{1}$, nie istnieje jedna powszechna definicja tego pojęcia (Hills, Lumpkin, Singh 1997). Wynika to przede wszystkim z wieloaspektowości tego zagadnienia, wykraczającego znacznie poza zakres samej tylko ekonomii i sytuującego się na pograniczu wielu innych nauk, m.in. psychologii, socjologii, geografii ekonomicznej. Można przy tym wyróżnić dwa zasadnicze podejścia (Kasperkiewicz, Mikosik 1993, Kaleta 1997):

- pierwsze definiuje przedsiębiorczość jako zespół procesów związanych z powstawaniem nowych i rozwojem istniejących podmiotów gospodarczych (por. Gartner 1988);

- drugie skupia się na świadomościowym wymiarze przedsiębiorczości, traktując je jako jedną z form zachowania społecznego (Kaleta 1997) czy też badając je z punktu widzenia cech osobowych jednostek przedsiębiorczych (Faris 1999). W takim ujęciu nie ogranicza się więc tylko do sfery gospodarczej, jakkolwiek z niej się wywodzi. Odnosi się do wszystkich działań ludzkich oprócz tych, które można określić jako egzystencjalne (Drucker 1992).

Stosowane definicje z reguły podkreślają silny związek przedsiębiorczości z innowacyjnością (Hills, Lumpkin, Singh 1997) bądź utożsamiają wręcz oba te zjawiska (Schumpeter 1960, Drucker 1992). W tym ostatnim rozumieniu przedsiębiorcą jest więc tylko ten, kto wprowadza innowacje. $Z$ tego punktu widzenia nie każde nowe przedsiębiorstwo może być uznane za przejaw przedsiębiorczości; zarazem przedsiębiorcze mogą być osoby fizyczne spoza kręgu właścicieli różnego typu podmiotów gospodarczych.

Wyniki badań wskazują na bardzo szeroki i wieloraki wpływ przedsiębiorczości na procesy wzrostu gospodarczego oraz sferę społeczną. Przejawiać się on może przez (Kayne 1999):

- odkrywanie i wprowadzanie w życie produktów i usług, które przyczyniają się do poprawy jakości życia oraz powodują zmianę pozycji określonych obszarów w światowej ekonomii;

- powstawanie nowych przemysłów i przedsiębiorstw zastępujących stare;

- tworzenie miejsc pracy;

- kreowanie bogactwa, które może być reinwestowane w nowe przedsiębiorstwa i przekazywane społeczeństwu.

Jedną z ważniejszych prób empirycznego pomiaru zjawiska przedsiębiorczości podjęto w końcu lat 90. XX w. w ramach projektu Global Entrepreneurship Monitor (GEM) (Minniti 1999). Podstawą wielu analiz było przyjęcie założenia, że przedsiębiorczość wyraża się poprzez jakąkolwiek próbę podjęcia nowego przedsięwzięcia, jak: samozatrudnienie, założenie

${ }^{1}$ Termin ,przedsiębiorczośćc” został wprowadzony do ekonomii przez badaczy francuskich w XVII w. (Dees 1998). 
nowego podmiotu gospodarczego czy ekspansja istniejącego przedsiębiorstwa. Badania przeprowadzono na poziomie wybranych krajów.

Podstawowym problemem związanym z analizą przedsiębiorczości jest wypracowanie obiektywnego i w miarę prostego sposobu pomiaru tego zjawiska. Analizy koncentrują się na dwóch aspektach.

1. Pomiar „ducha przedsiębiorczości”. Przeważają w tym wypadku badania ankietowe wybranych grup osób bądź określonych populacji. W wypadku analiz związanych z procesem powstawania nowych podmiotów gospodarczych studia wskazują na następujące przejawy przedsiębiorczości (Reynolds 2000):

- „aktywność startowa” wyrażająca się działaniami zorientowanymi na założenie nowego przedsiębiorstwa,

- „aktywność uśpiona” przejawiająca się brakiem takich działań w danej chwili, przy deklarowanym zamiarze stworzenia nowego przedsięwzięcia,

- „aktywność przerwana” - podjęta próba, niezakończona sukcesem,

- „narodziny firmy” - podjęta próba zakończona sukcesem, tzn. powstaniem nowego podmiotu gospodarczego.

$\mathrm{Na}$ ich podstawie tworzone są różnego rodzaju wskaźniki pomiaru przedsiębiorczości, np. (Arenius, Autio 2000) ogólny wskaźnik przedsiębiorczości (TEA) ${ }^{2}$, liczony jako suma wskaźników:

- „aktywności startowej” - udział ludności w wieku produkcyjnym podejmującej próbę założenia nowego podmiotu gospodarczego,

- upowszechnienia przedsiębiorczości - udział podmiotów nowo założonych (w ciągu ostatnich 42 miesięcy) w ogólnej liczbie podmiotów gospodarczych,

- partycypacji finansowej inwestorów indywidualnych - udział osób w wieku produkcyjnym, które w określonym czasie przekazały fundusze na rozwój innych przedsięwzięć (firm).

Wskaźniki te, ze względu na konieczność prowadzenia szeroko zakrojonych badań ankietowych i wynikających z tego znacznych kosztów, w przekrojach terytorialnych stosowane były głównie do porównań międzykrajowych, np. w ramach projektu GEM (por. Minniti 1999, Arenius, Autio 2000, Reynolds i inni 2001, Reynolds i inni 2002].

2. Pomiar efektów przedsiębiorczości. Najczęściej przedmiotem analizy jest w tym wypadku liczba różnego typu przedsiębiorstw odniesiona do populacji ludzkiej lub ogólnej populacji podmiotów gospodarczych. Konstruowane w ten sposób wskaźniki, ze względu na możliwość wykorzystania do ich obliczenia danych zbieranych przez statystykę publiczną, stosowane są powszechnie w literaturze. Spotkać można różne ich warianty, np.:

- przyrost „,netto” przedsiębiorstw, tzn. różnica między podmiotami zarejestrowanymi i wyrejestrowanymi (Hryniewicz 1998);

- wskaźnik przyrostu przedsiębiorstw - przyrost „netto” przedsiębiorstw odniesiony do ogólnej liczby podmiotów gospodarczych lub liczby ludności (Reynolds 2000);

- dynamika przyrostu podmiotów gospodarczych (Kamińska 1993, Gałązka, Mync 1994, Rydz, Jażewicz 2001);

- wskaźnik stabilizacji sektora prywatnego - stosunek liczby przedsiębiorstw zarejestrowanych do liczby przedsiębiorstw wyrejestrowanych w danym roku (Kowalczyk, Wilk 1994, Gorzelak, Jałowiecki 1996):

- liczba podmiotów gospodarczych sektora małych i średnich przedsiębiorstw na 1000 mieszkańców ogółem (Schuttenbach 2000) lub w wieku produkcyjnym (Sechster..., 1999);

${ }^{2}$ TEA - Total Entrepreneurship Activity Rate. 
- liczba podmiotów gospodarczych na 1000 mieszkańców ogółem (Maryáš 2000, Czyżewski i inni 2001, Zintegrowany..., 2003) lub 1000 mieszkańców w wieku produkcyjnym (Jakubowicz, Raczyk 1998, Głębocki 2000).

Podstawowym założeniem badań opartych na drugim z prezentowanych podejść jest przyjęcie, że przedsiębiorczość wyraża się poprzez powstawanie nowych podmiotów gospodarczych. Zawęża to w pewnym stopniu samą definicję zjawiska, umożliwia jednak jego ilościową charakterystykę opartą na dostępnych danych statystycznych (np. rejestr REGON). W odniesieniu do warunków panujących w Polsce, wybór sposobu pomiaru wymaga również uwzględnienia wielu dodatkowych okoliczności, specyficznych dla okresu transformacji systemowej:

- wartości cech dotyczących nowych zjawisk w polskiej gospodarce praktycznie zawsze są determinowane ich dynamiką w okresie poprzedzającym. Powoduje to, że konstruowane wskaźniki stanu oraz dynamiki zawierają bardzo podobny zakres informacji;

- w okresie wyjściowym (tzn. stanowiącym początek transformacji) wiele zjawisk miało bardzo niskie wartości lub wręcz nie występowało ${ }^{3}$. Z tego względu stosowanie wskaźników dynamiki rodzi znaczne problemy interpretacyjne;

- istotnym problemem jest wliczanie podmiotów sektora publicznego do wskaźników przedsiębiorczości. Należy pamiętać, że istotną rolę w ich kreacji odgrywają inne przyczyny, niezwiązane bezpośrednio z przytoczonymi definicjami przedsiębiorczości. Zmiana liczby podmiotów sektora publicznego dokonuje się bowiem głównie poprzez wzrost liczby podmiotów powoływanych przez organy administracji rządowej i samorządu terytorialnego (por. Zmiany strukturalne..., 2001) lub podział większych jednostek publicznych w związku $\mathrm{z}$ ich restrukturyzacją (zjawisko to występowało szczególnie w początkowym okresie transformacji).

Zważywszy na powyższe stwierdzenia wydaje się, że z punktu widzenia pomiaru efektów przedsiębiorczości najbliższy przytoczonym definicjom jest pomiar zjawiska za pomocą wskaźnika liczby podmiotów gospodarczych sektora prywatnego w odniesieniu do liczby potencjalnych przedsiębiorców (mieszkańców w wieku produkcyjnym i poprodukcyjnym). Należy przy tym pamiętać, że w praktyce badawczej w Polsce ostateczny sposób pomiaru w ostateczności weryfikowany jest przez relatywnie ubogi publicznie dostępny materiał empiryczny.

\section{Możliwości badań opartych na rejestrze REGON}

Potencjalnym źródłem informacji o liczbie podmiotów gospodarczych są rejestry prowadzone przez administracyjne systemy informacji. Istniejący dotychczas w Polsce system prawny powodował jednak skomplikowany i sztuczny podział przedsiębiorstw na podlegające rejestrowi sądowemu (około 12 różnych rejestrów, np. osób prawnych, organizacji społecznych i zawodowych) oraz podlegające rejestrowi administracyjnemu (około 2000 rejestrów gminnych bez centralnej informacji dotyczące np. osób fizycznych prowadzących działalność gospodarczą). W efekcie systemy te były rozproszone terytorialnie i organizacyjnie, co utrudniało ich wykorzystywanie (Nowicki 2001). Dopiero od roku 2001, zgodnie z ustawą o Krajowym Rejestrze Sądowym z 1997 r., przewidziano ujednolicenie i scentralizowanie systemu rejestracji podmiotów gospodarczych. $Z$ tego względu jedynym wiarygodnym i w miarę kompleksowym zbiorem informacji dotyczącej tych podmiotów jest Krajowy Rejestr Urzędowy Podmiotów Gospodarki Narodowej z 1995 r. (KRUPGN), prowadzony przez GUS. Zgodnie z ustawą o statystyce publicznej z 1995, KRUPGN służy jako podstawa spójności identyfikacyjnej, pojęciowej i klasyfikacyjnej rejestrów urzędowych systemów informacyjnych administracji

${ }^{3}$ Tzn. nie było odnotowywane przez statystykę publiczną. 
publicznej, poprzez obowiązek posługiwania się przez wszystkie te rejestry numerem identyfikacyjnym REGON.

Ustawowy wymóg wpisu do rejestru REGON obejmuje trzy typy jednostek prawnych: osoby prawne, osoby fizyczne oraz jednostki organizacyjne nieposiadające osobowości prawnej, jak również ich jednostki lokalne. Szczególnie istotne, z punktu widzenia badań przestrzennych, jest uwzględnianie w rejestrze jednostek lokalnych podmiotów gospodarczych. Do jednostek lokalnych zalicza się (Zmiany strukturalne..., 2001):

- zakłady samodzielnie sporządzające bilans;

- objęte odrębną rejestracją prawną organizacyjne części podmiotów gospodarczych;

- jednostki prowadzące działalność w zakresie transportu, z których wydawane są polecenia lub w których organizowana jest praca;

- jednostki prowadzące działalność w zakresie budownictwa, w których przyjmowane są zlecenia na wykonawstwo robót budowlanych i pomocniczych, wykonywane są prace zarządu albo jest prowadzona organizacja pracy budowlanej i pomocniczej (poza placami budów);

- miejsce zamieszkania osoby fizycznej (siedziba osoby prawnej lub jednostki organizacyjnej nieposiadającej osobowości prawnej) prowadzącej sprzedaż obwoźną, obnośną, punkt sprzedaży detalicznej bez stałej lokalizacji oraz wykonującej usługi wyłącznie u klienta.

Uwzględnienie jednostek lokalnych powoduje, że zbierane przez rejestr informacje pokazują zbliżony do rzeczywistego rozkład przestrzenny podmiotów gospodarczych, a nie tylko lokalizację ich ,central”. Ma to bardzo duże (choć często nieuświadomione) znaczenie dla badań naukowych prowadzonych na ich podstawie.

Przepisy regulujące rejestr podmiotów gospodarki narodowej istnieją już od ponad trzydziestu lat i wielokrotnie ulegały modyfikacjom. W początkowych latach transformacji systemowej istniejący stan prawny powodował jednak, że większość podmiotów gospodarczych nie dopełniała formalności rejestracyjnych, ponieważ nie wiązało się to z sankcjami prawnymi. W efekcie ewidencja obejmowała niewielką ich część, ograniczoną z reguły do jednostek największych. Dopiero od 1993 r. można mówić o reprezentatywności rejestru REGON. Wprowadzenie podatku VAT i przepisów wiążących możliwość dokonywania odpisów od tego podatku z wymogiem posiadania numeru REGON spowodowały masową rejestrację podmiotów gospodarczych (Churski 1995). Od roku 1995, zgodnie z ustawą o statystyce publicznej, uzyskanie wpisu do rejestru REGON stało się niezbędnym warunkiem istnienia praktycznie wszystkich typów podmiotów gospodarczych. Jedynie część stowarzyszeń i innych instytucji non-profit, przede wszystkim nieprowadzących działalności finansowej, pozostaje nieuwzględniona w ewidencji. Stanowią one jednak bardzo niewielki procent ogólnej liczby podmiotów gospodarczych, dlatego można przyjąć założenie o kompletności tego rejestru.

Raz nadane numery, nawet w przypadku likwidacji podmiotu, nie są wykorzystywane do identyfikacji innych jednostek. W celu aktualizacji swoich zasobów KRUPGN współpracuje m.in. z systemem Krajowej Ewidencji Podatników POLTAX, rejestrami sądowymi, ewidencją działalności gospodarczej, systemem ubezpieczeń społecznych ZUS (por. Polska statystyka..., 1998).

Podstawowym problemem rejestru REGON jest jego nadreprezentatywność. O ile uwzględnia on praktycznie wszystkie powstające podmioty gospodarcze, o tyle system ewidencji podmiotów, które zaprzestały działalności (zawiesiły ją bądź zostały zlikwidowane), jest bardzo niedoskonały. Z badań GUS wynika, że zaledwie około 60\% zarejestrowanych podmiotów gospodarczych można uznać za aktywne. Spośród pozostałych około 8\% nie podjęło działalności pomimo jej zarejestrowania, a ponad $30 \%$ czasowo lub całkowicie zaprzestało prowadzenia działalności gospodarczej (tab. 1). 
Tab. 1. Podmioty gospodarcze zarejestrowane w systemie REGON według stanu aktywności w latach 1995-2004 (w \%)

\begin{tabular}{|l|c|c|c|c|c|}
\hline \multicolumn{1}{|c|}{ Podmioty gospodarcze } & $\mathbf{1 9 9 5}$ & $\mathbf{1 9 9 6}$ & $\mathbf{1 9 9 7}$ & $\mathbf{1 9 9 8}$ & $\mathbf{2 0 0 4}$ \\
\hline Aktywne & 60,0 & 63,3 & 67,9 & 61,7 & 55,8 \\
\hline Nieaktywne, w tym takie, które: & 40,0 & 36,7 & 32,1 & 38,3 & 44,2 \\
\hline $\begin{array}{l}\text { - całkowicie zaprzestały } \\
\text { prowadzenia działalności } \\
\text { bez zamiaru jej wznowienia }\end{array}$ & 29,1 & 26,9 & 23,1 & 22,7 & 24,6 \\
\hline - czasowo zaprzestały prowadzenia \\
$\begin{array}{l}\text { działalności z zamiarem jej } \\
\text { wznowienia w przyszłości }\end{array}$
\end{tabular}

* Dane dla podmiotów o liczbie pracujących do 9.

Źródło: opracowanie autora na podstawie: Warunki prowadzenia..., 2001, Działalność gospodarcza..., 2005.

Oparcie badań naukowych na rejestrze REGON ma zatem określone następstwa. Powstanie nowego podmiotu gospodarki narodowej jest utożsamione $\mathrm{z}$ faktem nadania mu numeru identyfikacyjnego i wpisu do ewidencji. Za nowy podmiot uznawana jest sama próba podjęcia działalności, bez względu na to, czy zakończyła się ona pomyślnie (przedsiębiorstwo ostatecznie powstało i uruchomiło działalność) i czy jej efekt (tzn. dana jednostka) istnieje nadal. W tym kontekście rejestr REGON stanowi dobre narzędzie pomiaru „ducha przedsiębiorczości”.

Należy mieć przy tym na uwadze fakt, że rejestr REGON jest zbiorem bardzo zróżnicowanych ze względu na liczebność, sposób kreacji i wpływ na sferę społeczną i gospodarczą grup podmiotów gospodarki narodowej. Z punktu widzenia dokładności badania oraz możliwości interpretacyjnych celowa wydaje się więc analiza poszczególnych elementów składowych charakteryzujących te podmioty. W szczególności uwzględnienia wymagają: ich aktualny, rzeczywisty status, lokalizacja, przedmiot działalności oraz liczba pracujących.

\section{Weryfikacja kompletności rejestru REGON}

\section{Status podmiotów}

W trakcie badania, biorąc pod uwagę status, wydzielono następujące grupy jednostek:

- zinwentaryzowane, brak informacji. Objęła ona podmioty istniejące i aktywnie działające (widoczne przejawy aktywności), które ze względu na różne czynniki (w tym najczęściej brak obecności właściciela lub zdecydowaną odmowę udzielenia informacji) nie mogły zostać objęte badaniem ankietowym;

- istniejące. Oznaczało to grupę jednostek faktycznie istniejących, które zostały poddane badaniu ankietowemu;

- niezinwentaryzowane, przeniesione. Status taki występował wówczas, gdy uległa zmianie lokalizacja jednostki w sposób uniemożliwiający stwierdzenie jej istnienia i przeprowadzenia badania ankietowego (np. przeniesienie poza miasto); 
- niezinwentaryzowane, brak informacji. Taki status był przypisywany podmiotom, które nie przejawiały działalności w przestrzeni miejskiej, przy czym - ze względu na nieobecność osób mogących udzielić informacji - nie można było przesądzić o istnieniu lub zaprzestaniu działalności przez te jednostki. Grupa ta obejmowała z reguły podmioty gospodarcze osób fizycznych, których miejsce zarejestrowania (mieszkanie prywatne) i miejsce prowadzenia rzeczywistej działalności gospodarczej (np. gmina, region) były różne (np. agenci ubezpieczeniowi, akwizytorzy);

- niezinwentaryzowane, nieodnalezione. W podanym w rejestrze adresie brak było jakichkolwiek przejawów działalności danego podmiotu oraz jednoznacznej informacji o zaprzestaniu działalności. W odróżnieniu od grupy poprzedniej, jednostki te nie były zlokalizowane w mieszkaniach prywatnych. Prawdopodobnie zdecydowana większość z nich zaprzestała działalności; - nieistniejące. Powyższy status obejmował jednostki, dla których uzyskano informacje o zaprzestaniu prowadzenia działalności gospodarczej.

Wyniki badania pokazały dużą złożoność populacji podmiotów gospodarki narodowej ze względu na status, czego skutkiem była konieczność wyjścia poza schemat jednostki istniejące - jednostki nieistniejące (ryc. 1). Zaledwie około 34\% podmiotów zarejestrowanych w systemie REGON było jednoznacznie możliwych do zidentyfikowania w przestrzeni miasta Milicza. Ponad $43 \%$ jednostek nie istniało, a status około $26 \%$ był trudny do ustalenia. W tej ostatniej grupie prawdopodobnie przeważały podmioty nieistniejące.

Ryc. 1. Struktura podmiotów gospodarki narodowej według statusu - Milicz, czerwiec 2006 r. (w \%)

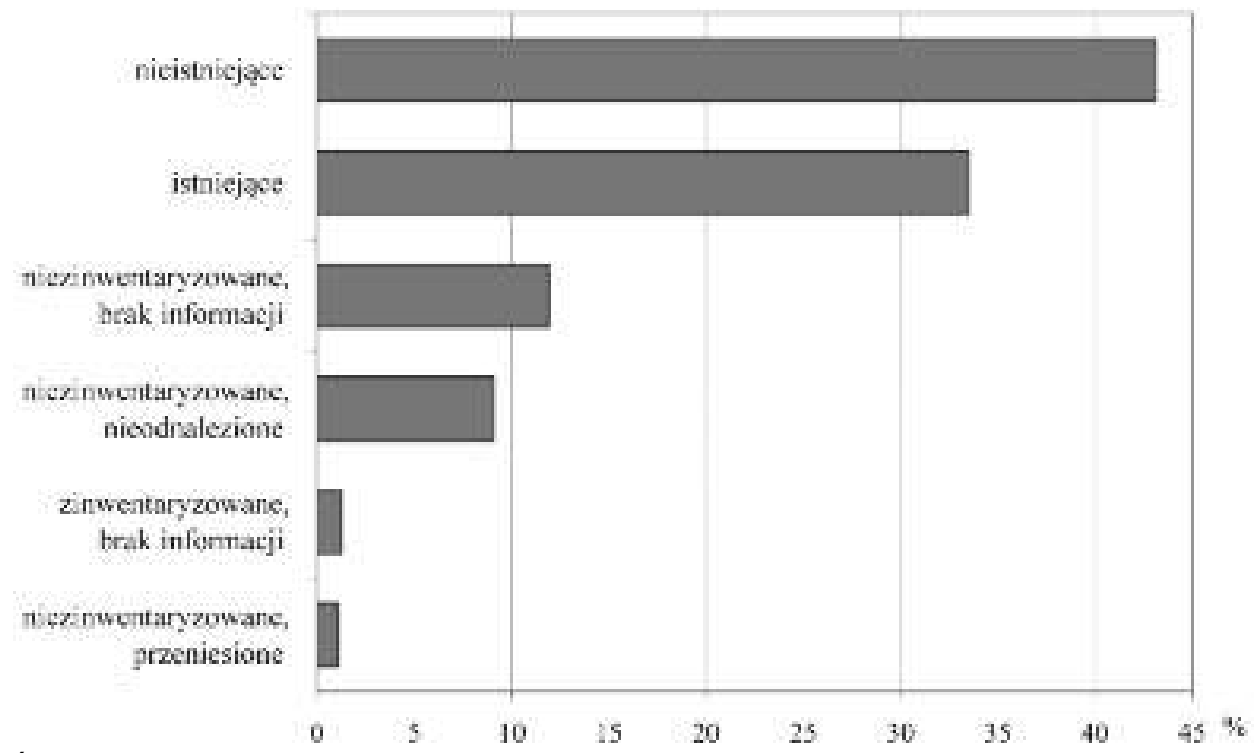

Źródło: opracowanie autora.

Ponadto w przestrzeni miasta zidentyfikowano 195 podmiotów (ponad 12\% bazy wyjściowej), których nie można było w żaden sposób zakwalifikować do rejestru REGON z powodu zmiany nazwy, adresu, lokalizacji lub profilu działalności. Istnienie tych jednostek wiązało się prawdopodobnie z następującymi przyczynami:

- zmianą szyldu, nazwy lub profilu działalności, bez uaktualnienia tych informacji w rejestrze;

- powstaniem w okresie od zakupu bazy danych do momentu przeprowadzenia badania (2 miesiące);

- rejestracją tych jednostek na innym obszarze i przeniesieniem działalności na teren miasta. Wydaje się, że najważniejszą rolę odgrywał czynnik pierwszy, tzn. niedopełnienie obowiązku statystycznego, jakkolwiek ta konstatacja nie może zostać potwierdzona empirycznie. 
Łącznie w grupie wszystkich przebadanych jednostek podmioty aktywnie działające stanowiły około $46 \%$. Wynik ten był nieco niższy niż w okresowych szacunkach stanu aktywności przeprowadzanych przez GUS (por. tab. 1). Należy przy tym pamiętać, że te szacunki dotyczyły tylko populacji podmiotów gospodarczych, a w badaniu uwzględniono wszystkie podmioty gospodarki narodowej.

\section{Główny profil działalności}

Oprócz znaczących różnic w liczebności poszczególnych subpopulacji, duże zmiany były obserwowane również w strukturze rodzajów działalności podmiotów gospodarki narodowej w zależności od ich statusu (ryc. 2).

Badanie wykazało, że rzeczywista liczba jednostek najbardziej odbiegała od wielkości statystycznej w obrębie instytucji otoczenia biznesu (sekcje K, J), budownictwa (F) i rolnictwa (A). Inaczej mówiąc, były one najbardziej nadreprezentowane w rejestrze. Może to świadczyć o dużej zmienności liczby jednostek w tych sekcjach, tzn. o wysokim tempie powstawania nowych podmiotów, przy jednoczesnym niskim wskaźniku ich ,przeżywalności”. Najbliższe stanu faktycznemu były informacje w sekcjach L, O, N, M, ponieważ w tych sekcjach duże znaczenie miały jednostki większe, przynależne do sektora publicznego. Takie jednostki $\mathrm{z}$ reguły wykazują się wyraźnie większym zdyscyplinowaniem w zakresie dopełniania obowiązków statystycznych niż np. mikroprzedsiębiorstwa. Jednocześnie w ich obrębie tempo powstawania nowych i likwidacji istniejących podmiotów było zdecydowanie mniejsze.

Na szczególną uwagę zasługują instytucje sekcji obsługa nieruchomości i firm (sekcja K). Nieproporcjonalnie duży udział jednostek nieistniejących lub o nieustalonym statusie wynikał m.in. z dynamicznego powstawania wspólnot mieszkaniowych pod koniec lat 90. XX w. Obecnie stanowią one prawie $60 \%$ wszystkich podmiotów w tej sekcji. W wyniku tego obserwowany statystyczny wzrost liczby i znaczenia podmiotów sektora otoczenia biznesu (sekcje J, K) czy tzw. usług rynkowych nie zawsze jest związany z korzystnymi przemianami strukturalnymi gospodarki. Wnioskowanie w tym wypadku powinno zatem być szczególnie ostrożne i w miarę możliwości wsparte analizą na poziomie działów PKD, np. w odniesieniu do sektorów według poziomów techniki (por. Raczyk, Dobrowolska-Kaniewska 2007).

Należy podkreślić bardzo duże zróżnicowanie udziału istniejących podmiotów w ogólnej liczbie zarejestrowanych w systemie REGON w podziale na sekcje PKD. Wahało się ono od około $11 \%$ (sekcja K) do prawie 70\%. Wskazuje to, że rzeczywiste struktury gospodarcze poszczególnych układów terytorialnych kształtują się nieco inaczej niż wykazuje statystyka publiczna.

W grupie jednostek istniejących aż 26\% wykazało odmienny (w porównaniu z deklarowanym w rejestrze) profil działalności według grup PKD (zmiana przynależności na poziomie sekcji miała raczej charakter incydentalny). Najczęściej wynikało to wielobranżowego charakteru działalności i elastycznego dostosowywania się do aktualnych potrzeb rynku lokalnego. Stanowiło również konsekwencję rozbieżności między oczekiwaniami przedsiębiorców w momencie rejestracji działalności w systemie REGON a rzeczywistym rodzajem podjętej działalności (efekt „rejestracyjny”).

Łączny efekt różnic pomiędzy statystyczną liczbą podmiotów a ich liczbą realną sprawia, że badanie struktur gospodarczych oraz przedsiębiorczości w układach przestrzennych oparte na rejestrze REGON jest możliwe tylko przy uwzględnieniu następujących założeń:

- podobieństwa struktury podmiotów gospodarki narodowej badanych jednostek terytorialnych ze względu na status tych podmiotów;

- podobieństwa udziału istniejących podmiotów w układzie sekcji (działów) PKD. 
Ryc. 2. Struktura podmiotów gospodarki narodowej według sekcji PKD oraz statusu - Milicz, czerwiec 2006 r.

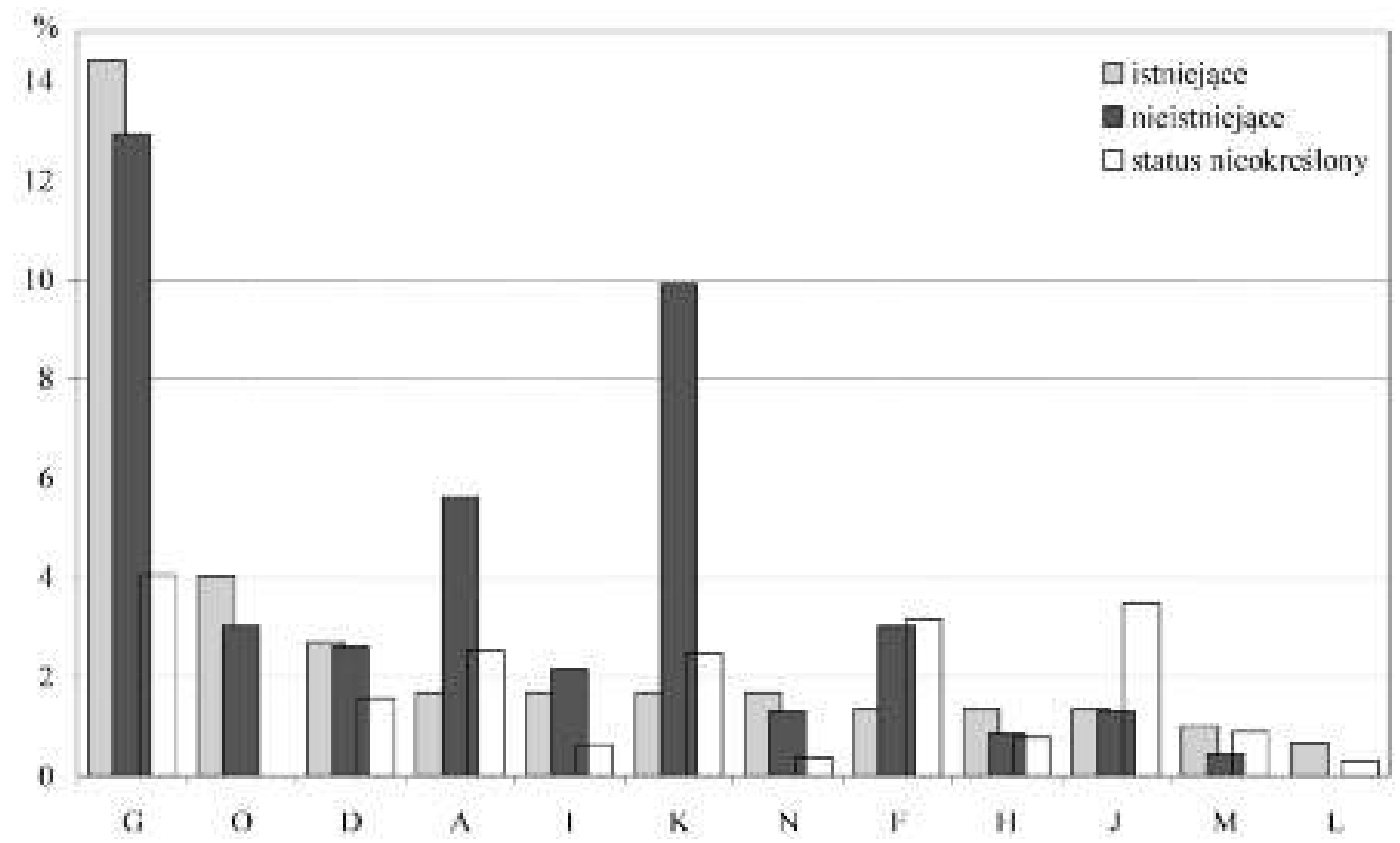

Źródło: opracowanie autora.

\section{Rynek pracy}

Badanie rynku pracy jest nieodzownym elementem analiz poziomu rozwoju społeczno-ekonomicznego poszczególnych obszarów, w tym również zjawiska przedsiębiorczości. Na poziomie lokalnym takie badanie jest poważnie utrudnione z powodu niedostatków statystyki publicznej. Dostępne informacje obejmują tylko liczbę i strukturę pracujących według trzech sektorów w grupie podmiotów o liczbie pracujących powyżej 9 osób (do roku 1999 - powyżej 5 osób). W skali kraju obejmują więc niespełna $60 \%$ całego rynku pracy, przy czym ten udział jest bardzo zróżnicowany przestrzennie i sektorowo. W zasadzie uniemożliwia to szczegółową analizę rzeczywistego wpływu przedsiębiorczości na lokalne rynki pracy.

Przeprowadzenie przez autora badań ankietowych, z uwagi na różnorodność statusu podmiotów gospodarki narodowej, okazało się zadaniem bardzo skomplikowanym. Problemy wiązały się z brakiem dostatecznych informacji lub odmową udzielenia odpowiedzi przez respondentów. Dlatego też - oprócz ankiet - dokonano szacunku liczby pracujących na podstawie klas wielkościowych podmiotów gospodarki narodowej, tzn. jednostek mikro- (do 9 pracujących), małych (10-49), średnich (50-249) i dużych (powyżej 250 pracujących).

Spośród uwzględnionych w ankietach jednostek 10\% zmieniło klasę wielkości według liczby pracujących, najczęściej między klasą mikro- (do 9 pracujących) a małą (10-49 pracujących). Dla określenia rynku pracy całego miasta kluczowe było określenie liczby jednostek istniejących i aktywnych o wielkości 1-9 pracujących (ponieważ nie są one uwzględniane w statystyce rynku pracy). Liczbę pracujących w instytucjach, które odmówiły odpowiedzi, oszacowano na podstawie średniej liczby pracujących w podmiotach, które odpowiedzi udzieliły. Określona na tej podstawie liczba pracujących ogółem (4239) była bardzo zbliżona do wielkości rynku pracy według Narodowego Spisu Powszechnego z roku 2002 r. (4246). Mając na uwadze relatywnie niewielkie zmiany wielkości rynku pracy Milicza w okresie 2002-2006 można założyć, że uzyskany wynik był zbliżony do wartości rzeczywistej.

Badanie pokazało, że na podstawie kryterium przynależności do klasy wielkościowej istniejących instytucji zawartej w rejestrze REGON można dokonywać stosunkowo precyzyjnego 
szacowania wielkości całego lokalnego rynku pracy. Jednocześnie jednak szacowanie struktury rynku pracy tylko na podstawie rejestru REGON może nie przynieść spodziewanych efektów. Wymagałoby to uwzględnienia dodatkowych informacji, np. zróżnicowania średniej wielkości jednostek według sekcji PKD oraz statusu tych jednostek (istniejąca, nieistniejąca). Dlatego badanie struktur gospodarczych układów lokalnych (gmin, powiatów) w Polsce oparte na statystyce publicznej powinno być dokonywane przede wszystkim na podstawie struktury podmiotów gospodarki narodowej (przy uwzględnieniu opisanych wcześniej założeń), a nie struktury pracujących.

\section{Lokalizacja i czas powstania}

Jednym z najistotniejszych elementów badań podmiotów gospodarki narodowej z punktu widzenia geografii ekonomicznej jest kształtowanie się określonych struktur przestrzennych tych podmiotów. W kontekście przedstawionych wcześniej wniosków przedmiotem analizy przeprowadzonej na podstawie danych empirycznych było poszukiwanie prawidłowości w rozmieszczeniu podmiotów ze względu na status, czas powstania oraz profil działalności.

Struktury przestrzeni instytucjonalnej od początku transformacji systemowej miały generalnie charakter trwały, tzn. struktury ukształtowane w okresie inicjalnym w kolejnych przekrojach czasowych powielały się. Niewielkie zmiany wiązały się z powstaniem nowych centrów handlowych oraz rozbudową osiedli mieszkaniowych.

Z punktu widzenia statusu najwyższy udział jednostek aktywnie działających w momencie badania miały podmioty powstałe przed 1980 r. (ryc. 3). Było to oczywiste, ponieważ dotyczyło z reguły jednostek sektora publicznego, trwale wpisanych w przestrzeń instytucjonalną miasta (urzędy, szkoły, placówki opieki zdrowotnej itd.). Co ciekawe, relatywnie wysoki udział jednostek istniejących miały również podmioty powstałe w początkowym okresie transformacji (lata 1990-1993), co się wiązało z silną recesją gospodarczą i nasileniem zjawisk negatywnych w sferze społecznej i gospodarczej (bezrobocie, spadek dochodów firm i gospodarstw domowych, presja konkurencyjna ze strony firm zagranicznych itd.). Z reguły były to nowe jednostki, a ich sukces wiązał się prawdopodobnie z przewagą konkurencyjną wynikającą z efektu wczesnego wejścia na rynek oraz zagospodarowania nisz rynkowych.

Ryc. 3. Udział podmiotów gospodarki narodowej zarejestrowanych w REGON według roku powstania i statusu - Milicz, czerwiec 2006 r.

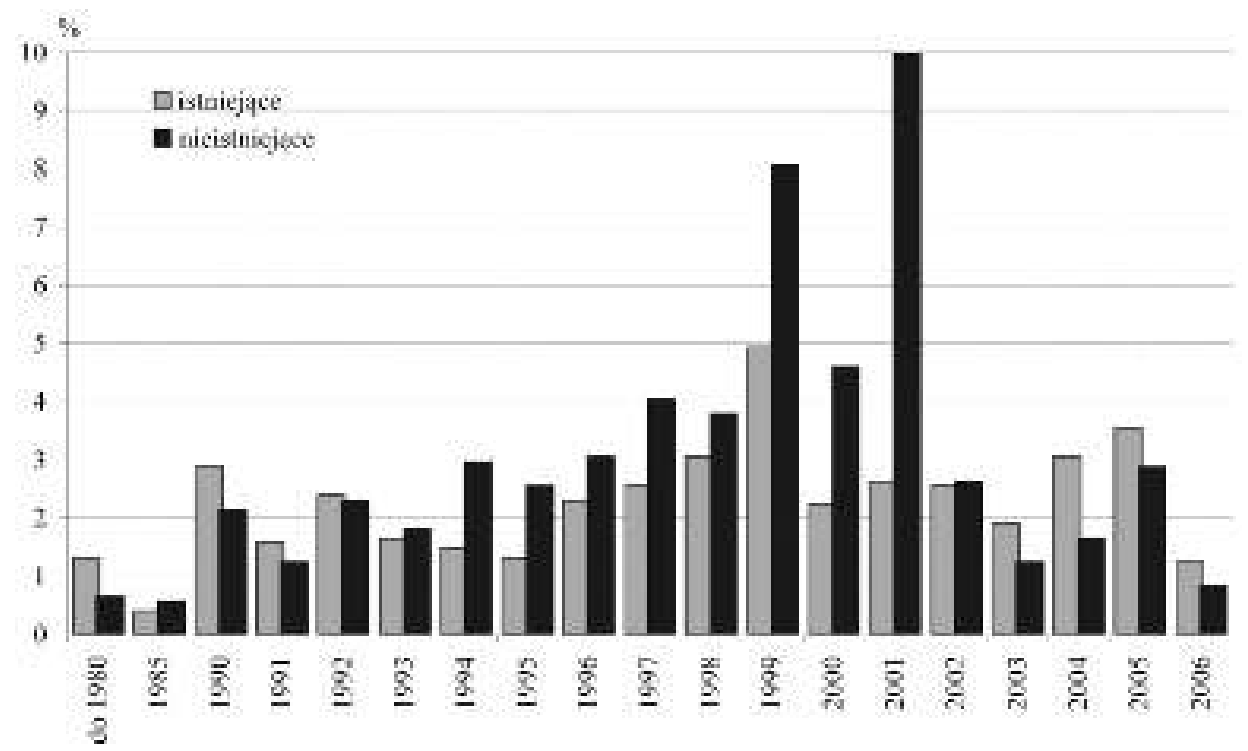

Źródło: opracowanie autora. 
Na uwagę zasługuje duża liczba podmiotów powstałych w latach 1999 i 2001. Przeważały wśród nich jednostki nieistniejące lub o nieustalonym statusie w momencie badania. Było to związane z rejestrowaniem wspólnot mieszkaniowych. W grupie jednostek powstałych w ciągu 3 lat poprzedzających badanie przeważały jednostki istniejące.

Ryc. 4. Lokalizacja podmiotów gospodarczych zarejestrowanych w systemie REGON w przestrzeni miasta Milicza według statusu w $2006 \mathrm{r}$.

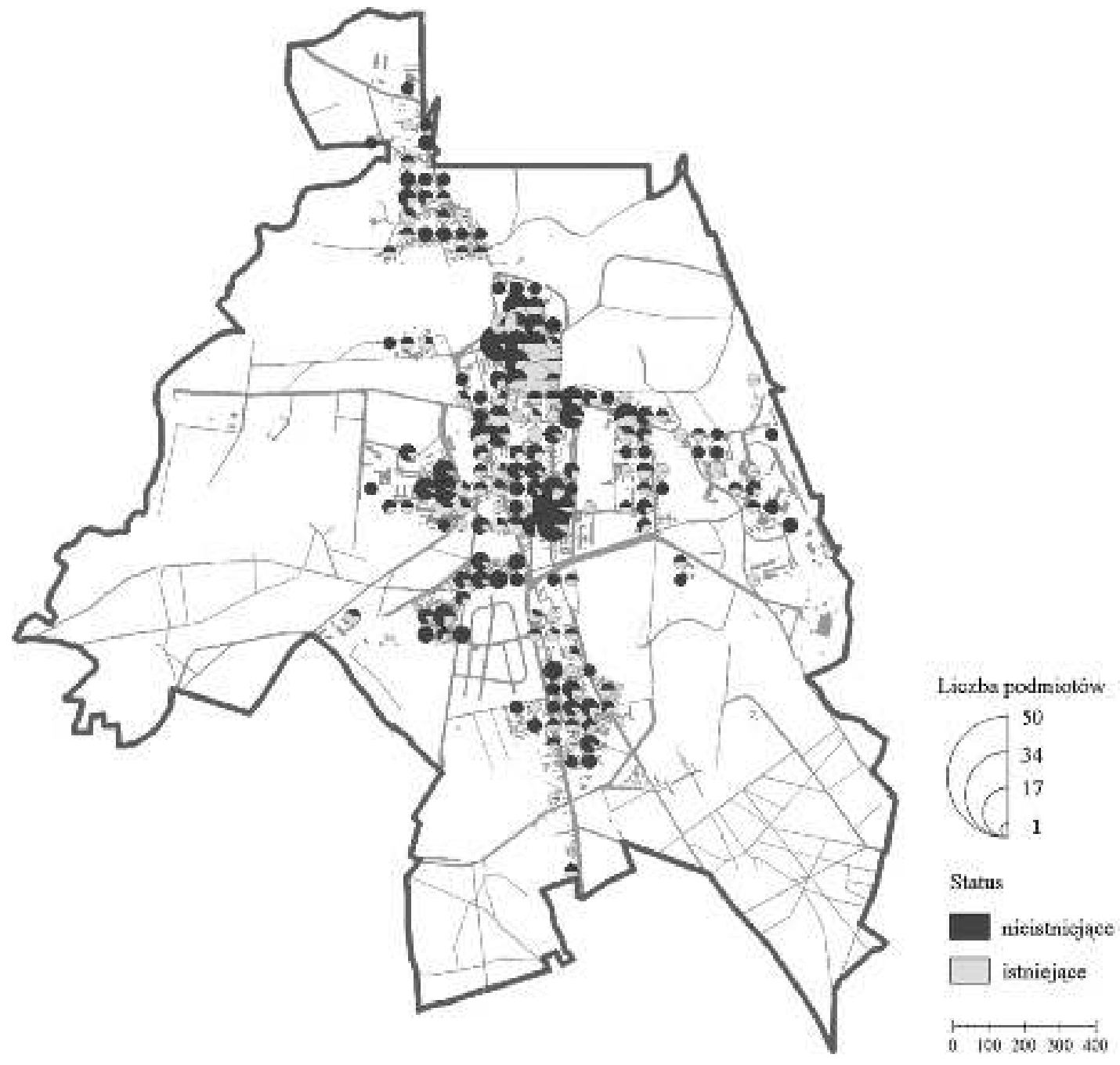

Źródło: opracowanie autora.

W strukturze przestrzennej zdecydowanie większa nadreprezentacja jednostek nieistniejących oraz o nieustalonym statusie była w obszarach peryferyjnych (ryc. 4). W centrum miasta wyraźnie dominowały instytucje o widocznej w przestrzeni formie działalności. Wskazuje to, że lokalizacja działalności gospodarczej ma pewien związek ze stopniem jej ,„przeżywalności”, zwłaszcza w odniesieniu do sektora handlu i usług podstawowych. Najwięcej podmiotów nieaktywnych zlokalizowanych było w obszarach oddalonych od centrum, z reguły na terenie dużych osiedli mieszkaniowych, tam bowiem najczęściej rejestrowane były podmioty osób fizycznych charakteryzujące się niskimi wskaźnikami przeżywalności oraz brakiem wyraźnych przejawów działalności w przestrzeni miasta (np. brak szyldu, osobnych pomieszczeń).

Podsumowując dotychczasowe wnioski, można stwierdzić, że chociaż realna i statystyczna przestrzeń instytucjonalna obejmuje podobne obszary miasta, to jednak intensywność wykorzystania przestrzeni w zależności od statusu jednostek jest różna. Należy to uwzględniać we wnioskowaniu. 


\section{Wnioski}

Jednoznaczne określenie, czy przedstawione wyżej prawidłowości mają charakter uniwersalny czy też są specyficzne dla poszczególnych obszarów, jest bardzo trudne. Biorąc pod uwagę zgodność z szacunkami przeprowadzonymi przez GUS w skali kraju, wydaje się, że na poziomie ogólnym mogą stanowić punkt odniesienia do analiz wykorzystujących rejestr REGON. Z pewnością powinny być uwzględniane konsekwencje wynikające z nadreprezentatywności tego rejestru, jego rzeczywistej struktury rodzajowej i wielkościowej oraz rzeczywistego rozmieszczenia przestrzennego. W świetle przeprowadzonych badań prowadzenie analiz dynamicznych podmiotów gospodarki narodowej $\mathrm{w}$ odniesieniu do układów lokalnych oraz regionalnych powinno mieć charakter przede wszystkim relatywny, tzn. odniesiony do innych jednostek terytorialnych. Przy założeniu podobieństwa struktur tych jednostek ze względu na status podmiotów, uzyskane wyniki pozwalają na poprawne wnioskowanie.

Najważniejszą kwestią związaną z prowadzeniem badań w przekroju wielu jednostek terytorialnych jest próba odpowiedzi na pytanie, czy wielkość różnic pomiędzy statystyczną liczbą podmiotów gospodarczych a ich liczbą realną ma charakter mniej więcej stały (uniwersalny), czy podlega ona istotnym zmianom. Jeżeli jest stała, to w zasadzie można ją uznać za nieistotną dla jakości analiz. Jeżeli jednak stała nie jest, rzutuje to istotnie na prawdziwość uzyskanych wyników. W takim wypadku konieczne byłoby szczegółowe poznanie prawidłowości determinujących powstawanie tych różnic i uwzględnienie ich $\mathrm{w}$ badaniach. Wymaga to jednak dalszych badań, w szczególności w odniesieniu do różnych jednostek terytorialnych (np. obszary wiejskie, miejskie, o niskim, o wysokim poziomie rozwoju). Takie badania w ograniczonym zakresie są planowane przez autora (np. dla innych obszarów miejskich).

Jednocześnie jednak, wobec niedostatków statystyki regionalnej i lokalnej, rejestr REGON może być źródłem bardzo wielu cennych informacji ze sfery społecznej i ekonomicznej, np. szacowania wielkości rynku pracy, określania rzeczywistych struktur gospodarczych, dynamiki rozwoju przedsiębiorczości. Wydaje się przy tym, że źródło to nie jest wykorzystywane $\mathrm{w}$ dostatecznym stopniu.

\section{Literatura}

1. Arenius P., Autio E., 2000, Global Entrepreneurship Monitor. Finnish Executive Report, Helsinki University of Technology.

2. Bagdziński S.L., Konkel J.A., 1997, Instrumenty promowania i wspierania rozwoju lokalnego i przedsiębiorczości $[\mathrm{w}] \mathrm{W}$. Maik, Problematyka rozwoju lokalnego w warunkach transformacji systemowej, „Biuletyn KPZK PAN”, z. 177.

3. Chmiel J., 1997, Mate i średnie przedsiębiorstwa a rozwój regionów, „Studia i Prace ZBSE”, GUS.

4. Churski P., 1995, Źródta i dostęp do informacji w badaniach lokalnych rynków pracy województwa poznańskiego [w] A. Jagielski, Zadania badawcze geografii społecznej i ekonomicznej w obliczu transformacji ustrojowej i restrukturyzacji gospodarcze, Materiały z konferencji, IG UWr, Wrocław.

5. Czyżewski A.B., Góralczyk-Modzelewska M., Saganowska E., Wojciechowska M., 2001, Regionalne zróżnicowanie kapitału ludzkiego w Polsce, ZBSE, GUS, Warszawa.

6. Dees J.G., 1998, The Meaning of Social Entrepreneurship, Stanford University.

7. Drucker P.F., 1992, Innowacja i przedsiębiorczość. Praktyka i zasady, PWE, Warszawa.

8. Działalność gospodarcza przedsiębiorstw o liczbie pracujących do 9 osób w 2004 r., 2005, GUS, Warszawa.

9. Faris S., 1999, Seeking Entrepreneurial Origins: Are Entrepreneurs Born or Made?, Kaufmann Center for Entrepreneurial Leadership, Kansas City.

10. Gałązka A., Mync A., 1994, Nowe miejsce sektora prywatnego w polskiej gospodarce ze szczególnym uwzględnieniem województwa warszawskiego [w] A. Mync, B. Jałowiecki, Przedsiębiorczość i prywatyzacja, „Biuletyn KPZK PAN”, z. 168. 
11. Gartner, W.B., 1988, "Who is an Entrepreneur?" is the Wrong Question, "American Journal of Small Business", 13/1988.

12. Głębocki B., 2000, Poziom rozwoju wielofunkcyjnego obszarów wiejskich Wielkopolski [w] A. Stasiak, Możliwości wielofunkcyjnego rozwoju wsi polskiej w kontekście integracji z Unia Europejska, „Studia KPZK”, PAN, SGGW, Warszawa, t. CX.

13. Gorzelak G., Jałowiecki B., 1996, Koniunktura gospodarcza i mobilizacja społeczna w gminach '95. Raport z I etapu badań, „Studia Regionalne i Lokalne”, EIRRiL, Warszawa.

14. Hills G.E., Lumpkin G.T, Singh R.P., 1997, Opportunity Recognition: Perceptions and Behaviors of Entrepreneurs, "Frontiers of Entrepreneurship Research", Babson College, Wellesley.

15. Hryniewicz J., 1998, Wymiary rozwoju gospodarczego gmin [w] G. Gorzelak, B. Jałowiecki, Koniunktura gospodarcza i mobilizacja społeczna $w$ gminach, EIRRiL, „Studia Regionalne i Lokalne", t. 25 (58).

16. Jakubowicz E., Raczyk A., 1998, Uwarunkowania wewnętrzne i zewnętrzne rozwoju obszarów górskich i górzystych Sudetów, RCSS BRR, Wrocław.

17. Kaleta A., 1997, Problematyka aktywizacji społeczności lokalnych [w] W. Maik, Problematyka rozwoju lokalnego w warunkach transformacji systemowej, „Biuletyn KPZK PAN”, z. 177.

18. Kamińska W., 1993, Rozwój indywidualnej dziatalności gospodarczej w województwach przygranicznych polski Poludniowo-Wschodniej [w] J. Kitowski J., Z. Zioło, Czynniki i bariery rozwoju regionów przygranicznych, Sekcja Gospodarki Przestrzennej KNE PAN oddz. w Krakowie, Wydział Ekonomiczny Filii UMCS w Rzeszowie, Instytutu Gospodarki Przestrzennej i Komunalnej w Warszawie, Kraków - Rzeszów - Warszawa.

19. Kasperkiewicz W., Mikosik S., 1993, Leksykon przedsiębiorczości, Uniwersytet Łódzki, Łódź.

20. Kayne J., 1999, State Entrepreneurship Policies and Programs, Kaufmann Center for Entrepreneurial Leadership, Kansas City.

21. Kowalczyk A., Wilk W., 1994, Rola sektora prywatnego w gospodarce lokalnej w strefie podmiejskiej Warszawa - na przykładzie gmin tomianki i Zielonka [w] A. Mync, B. Jałowiecki, Przedsiębiorczość i prywatyzacja, „Biuletyn KPZK PAN”, z. 168.

22. Maryáš J., 2000, Vybrané problémy hodnocení malého podnikání [w] S. Ciok, D. Ilnicki, Przeksztatcenia regionalnych struktur funkcjonalno-przestrzennych, Instytut Geograficzny UWr., Wrocław, t. V.

23. Minniti M., 1999, Global Entrepreneurship Monitor. National Entrepreneurship Assessment: Italy. Executive Report, Babson College, Wellesley.

24. Narodowa Strategia Rozwoju Regionalnego, 2000, Uchwała nr 105 Rady Ministrów z dnia 28 grudnia 2000 r. w sprawie przyjęcia Narodowej Strategii Rozwoju Regionalnego 2001-2006 (M.P. 2000, $\mathrm{Nr}$ 43, poz. 851).

25. Narodowy Plan Rozwoju, 2003, Ministerstwo Gospodarki, Pracy i Polityki Społecznej.

26. Nowicki A., 2001, Poradnik dla przedsiębiorców o Krajowym Rejestrze Sądowym, Polska Agencja Rozwoju Przedsiębiorczości, Warszawa.

27. Polska statystyka publiczna 1999, projekt, GUS, Warszawa 1998.

28. Raczyk A., 1999, Przekształcenia własnościowe w Polsce Poludniowo-Zachodniej w okresie transformacji systemowej [w] J. Łoboda, S. Grykień, Przekształcenia regionalnych struktur funkcjonalno-przestrzennych, Instytut Geograficzny UWr., Wrocław.

29. Raczyk A., Dobrowolska-Kaniewska H., 2007, Spatial distribution of economic entities and their classification according to technology levels in Dolnoślaskie Voivodeship, "Bulletin of Geography, socio-economic series”, no 7/2007, Nicolaus Copernicus University, Toruń, pp.15-29.

30. Reynolds P.D., 2000., National panel study of U.S. business startups: background and methodology, "Databases for the Study of Entrepreneurship", Vol. 4, JAI/Elsevier Inc.

31. Reynolds P.D., Bygrave W.D., Autio E., Cox L.W., Hay M., 2002, Global Entrepreneurship Monitor. 2002 Executive Report, Kauffman Center for Entrepreneurial Leadership, Kansas City.

32. Reynolds P.D., Camp S.M., Bygrave W.D., Autio E., Hay M., 2001, Global Entrepreneurship Monitor. 2001 Executive Report, Kauffman Center for Entrepreneurial Leadership, Kansas City.

33. Reynolds P.D., Hay M., Camp S.M., 1999, Global Entrepreneurship Monitor. 1999 Executive Report, Kauffman Center for Entrepreneurial Leadership, Kansas City. 
34. Rydz E., Jażewicz I., 2001, Zastosowanie metody statystyki pierwszych cyfr do typologii gmin Polski Pótnocnej $[\mathrm{w}] \mathrm{H}$. Rogacki, Koncepcje teoretyczne i metody badań geografii społeczno-ekonomicznej i gospodarki przestrzennej, Bogucki Wydawnictwo Naukowe, Poznań.

35. Schumpeter J., 1960, Teoria rozwoju gospodarczego, PWN, Warszawa.

36. Schuttenbach L., 2000, Sektor małych i średnich przedsiębiorstw w Republice Federalnej Niemiec, Polska Fundacja Promocji i Rozwoju Małych i Średnich Przedsiębiorstw, Warszawa.

37. Sechster Periodischer Bericht über die Regionen: Zusammenfassung der Hauptergebnisse, Regionalpolitik und Kohäsion, Europäische Union, Brüssel 1999.

38. Ustawa z 20 sierpnia 1997 r. o Krajowym Rejestrze Sadowym (Dz.U. Nr 121, poz. 769, z późn. zm.).

39. Ustawa z dnia 29 czerwca 1995 r. o statystyce publicznej (Dz.U. Nr 88, poz. 439, z późn. zm.).

40. Warunki powstawania i działania oraz perspektywy rozwojowe polskich przedsiębiorstw powstałych w latach 1995-1999, „Informacje i opracowania statystyczne”, GUS, Warszawa 2001.

41. Zintegrowany Program Operacyjny Rozwoju Regionalnego 2004-2006, Ministerstwo Gospodarki, Pracy i Polityki Społecznej, Warszawa 2003.

42. Zmiany strukturalne grup podmiotów gospodarki narodowej w I pótroczu 2001 r., „Informacje i opracowania statystyczne", GUS, Warszawa 2001.

\section{Methods for Examining Entrepreneurship on the Basis of the Register of Units of the National Economy}

One of the most important problems with examining entrepreneurship at the local level is the availability and quality of data gathered by public statistics. Registers conducted by administrative information systems are a potential source of information on the number, structure and spatial distribution of entities of the national economy. The most important role among them plays the Country Official Register of Units of the National Economy - REGON (KRUPGN REGON) conducted by Central Statistical Office.

The analysis of the REGON register is seriously hindered by its overrepresentativeness. Lack of detailed information on the scale of the phenomenon causes problems with interpretation of the obtained results. The basic purpose of conducted research was to verify the completeness of the register of economic entities its up-to-dateness from the point of view of information that describe these entities (status, location, number of persons employed). Moreover, it was checked whether the observed differences between the statistical and the real number of entities display any generic regularities (in PKD section) or spatial ones. This was obtained through the questionnaire survey of all the existing economic entities and comparison of the gathered data with the REGON register. Due to the scale of the research the analysis was conducted on the example of a medium-sized town (urban commune of Milicz) in 2006-2007.

The analysis has shown a variety of significant differences concerning the number of entities of the national economy as well as their size and type. It also allowed to define general characteristic features of spatial distribution the real signs of economic activity in the urban space. Although the conducted analysis concerned the relatively small settlement unit, it seems that the results obtained form the pattern that is reflected on the national scale. 